\title{
XXX. NOTES ON INDIAN COCCIDAE OF THE SUB-FAMILY DIASPIDINAE, WITH DESCRIPTIONS OF NEW SPECIES.
}

By E. Eirnest Green, F.E.S., F.Z.S.

(Plates XXVI-XXXI).

Since the publication of my last enumeration of Coccidae from the Continent of India ('Mem. Dep. Ag. Ind.' Ent. Ser., II, No. 2, Ap. I908), many fresh records have accumulated, including a considerable number of undescribed species. The present paper deals with those belonging to the sub-family Diaspidinae. describing the new species and listing others that have not previously been recorded from India. Of the fifty species now added to the Indian list, twenty are here described for the first time. It is only to be expected that, in such a vast and (in this respect) unexplored region, we can have touched no more than the fringe of the subject. Every fresh parcel that I receive discloses one or more novelties.

I am indebted to T. V. Ramakrishna Aiyar, of the Agricultural College, Coimbatore, for repeated consignments of valuable and interesting material. I have also had the privilege of examining collections from the Indian Museum, from the Agricultural Research Institute (Pusa), from the Forest Zoologist (Dehra Dun) and from the Poona Agricultural College.

\section{Diaspis cinnamomi-mangiferae, Newst.}

$$
\text { (P1. XXVI, fig. Ia). }
$$

Female puparium thin, semitranslucent, whitish, circular. Dried insect pallid: probably yellowish in life. Form similar to that of D. rosae: the thoracic area broad, the abdominal area constricted. Pygidium with median lobes smaller, narrower, and less divergent than in rosae.

On Mangifera indica: Bangalore (Ramakrishna, No. II4).

\section{Diaspis Ioranthi, Green.}

(P1. XXVI, fig. Ig).

On Loranthus cordifolius: Paresnath, Bihar, $4000 \mathrm{ft}$. (Ind. Mus. No. 7I). Differs from rosae in the larger, more prominent and more rounded median lobes, which extend far beyond the lateral lobes. Dr. Annandale writes of this species, "It has perhaps 
some economic importance, for it was strictly confined to the Loranthus upon which it was found in some abundance, and species of Loranthus have been known to do serious damage to forest timber in the Himalayas. I could find no trace of the Coccid on the tree on which the I,oranthus was growing."

\section{Diaspis rosae (Bouche).}

(P1. XXVI, fig. $\mathrm{I} b-f)$.

On Loranthus sp.: Ootacamund (coll. E.E.G). On Hemigyrosa: Courtallum, Tinnevelli District (Ramakrishna, No. I4I).

$D$. rosae varies considerably in the size of the median lobes; but they are always more or less pointed at the outer extremity, and scarcely project beyond the lateral lobes. Figs. $b$ to $f$ represent examples of rosae from different localities, showing a gradual increase in the size of the median lobes.

\section{Chionaspis annandalei, n. sp.}

(P1. XXVI, fig. $2 a-c)$.

Puparium of female sordid white, pellicles castaneous. Form elongate, straight or slightly curved, very narrow; underside with a ventral scale enclosing the insect and ova, except for a narrow median slit which remains open-as in Mytilaspis gloveri. Length 2 to $2.5 \mathrm{~mm}$. Greatest breadth $0.3 \mathrm{~mm}$.

Male puparium pure white, with a rather indistinct median carina: pellicle castaneous. Length $\mathrm{I}^{\prime} 25 \mathrm{~mm}$.

Adult female (fig. 2a) elongate, linear; the cepalo-thoracic area occupying more than half the length of the body. Pygidium (fig. $2 b$ ) with six prominent lanceolate lobes, of which the median are slightly the largest: the two lateral lobes are situated close together on each side, but are separated by a considerable interval from the median lobes. All the lobes have radices extending far back into the pygidium. There is a conspicuous marginal pore between the median lobes, one in the space between the median and lateral lobes, and others at intervals on each side beyond the 1obes. Squames spiniform. Anal and genital orifices near the base of the pygidium. There are no circumgenital pores. The oval dorsal pores are numerous and conspicuous, and are arranged as shown in the figure. Length I to $\mathrm{I} 5 \mathrm{~mm}$.

Nymphal pellicle (fig. 2c) with a well defined division between the thoracic and abdominal areas.

On stems of Dendrocalamus strictus. Paresnath Hill, 2500 ft., Bihar (N. Annandale, Io-iv-Igog).

Chionaspis caroli, n. sp.

(P1. XXVI, fig. $3 a-b)$.

Puparium of female snowy white; smooth; pellicles fulvous. Form elongate, moderately dilated behind. Owing to the position 
taken up by the insect (on the extreme margins of the leaves), the sides of the puparium are turned down, clasping the edge of the leaf (see fig. 3a). Average length $2 \mathrm{~mm}$.

Male puparium (see also fig. 3a) white; narrow elongate ; transverse section lenticular; without any trace of carinae; attached by the anterior extremity only, the rest of the scale tilted up from the leaf Average length I.5 mm.

Adult female narrow in front, widest across the abdomen, increasing in width up to the segment immediately preceding the pygidium. Lateral margins of abdominal segments moderately produced. Pygidium (fig. $3^{h}$ ) rounded. Median lobes very small, inconspicuously dentate on free edge: first lateral lobes duplex, the inner lobule large and conspicuous, with rounded entire margin, the outer lobule small and bluntly pointed, other lobes obsolete. Squames spiniform, tubular, unusually long and slender. Circumgenital glands in five groups: median group with from Io to I2 pores, upper laterals I5 to I7, lower laterals I4 to I6. Oval dorsal pores in short diagonal series on the pygidium and on the preceding two segments; other similar pores on margins of remaining abdominal segments, and-occasionally-on the margins of the thorax. Length $\mathrm{I}$ to $\mathrm{I} \cdot 25 \mathrm{~mm}$.

On leaves of tea plant: Darjiling (C. B. Antram). The female insects disposed along the recurved edge of the leaf; male puparia in small groups on the undersurface of the leaves.

The species is well characterized by the exceptionally small median lobes.

Although the male puparia are not carinated, I consider that the insect bears closer relationship to the genus Chionaspis than to Lepidosaphes, in which it might otherwise be included.

\section{Chionaspis chir, n. sp.}

\section{(P1. XXVI, fig. $4 a-e$; P1. XXVII, fig. $5 f$ ).}

Puparium of female snowy white; smooth and shining; pellicles reddish, often partially obscured by a layer of white secretion: long-ovate or pyriform, rather strongly convex in transverse section. Average length $2.75 \mathrm{~mm}$. Breadth $\mathrm{I}^{*} 4 \mathrm{~mm}$.

Male puparium not observed.

Adult female (fig. 4a) oblong ovate, narrower in front, broadly rounded behind. Anterior spiracles with a small group of parastigmatic pores. Lateral area of meso-thoracic and of the first three abdominal segments with numerous minute circular pores. Pygidium (fig. 5f) with evenly rounded margin, broken by four conspicuous pore-bearing prominences on each side: the extremity (between the innermost pair of marginal pores) varying-often asymmetrically -in almost every individual examined. In the most symmetrical form (fig. $4 d$ ), there is a small median conical point followed, successively, on each side, by a prominent lanceolate process, a broad tridentate process and an irregularly falcate 
process. The tridentate processes are probably homologous with the usual median lobes. The lateral lobes are possibly represented by a minute process immediately caudad of the second marginal pore. In one example (fig. $4^{c}$ ) all of the median processes have been suppressed, leaving the margin-at this part-irregularly sinuate. Squames represented (if at all) by a few minute projections towards the base of the pygidium. Circumgenital glands in four groups: the upper lateral group with from I3 to I7 pores, the lower laterals with from 34 to $4 \mathrm{I}$ pores. Dorsal oval pores numerous, large and conspicuous: in regular series following the contour of the suppressed segments. Anal orifice near the base of the pygidium. Length I'5 to $2 \mathrm{~mm}$.

On 'Chir Pine' (Pinus sp.): Almora, Kumaon, U.P. (coll. Forest Zoologist, Dehra Dun.)

It is with considerable hesitation that I have assigned this insect to the genus Chionaspis. The characters of the covering scale, and most of those of the insect itself, suggest its affinity to Maskell's genus Poliaspis. But that genus was founded especially to contain species possessing more than five groups of circumgenital pores, of which this insect has four only-an unusual number in any Diaspidine genus, except Parlatoria and Aspidiotus, with neither of which can this species be associated.

\section{Chionaspis (Phenacaspis) gudalura, n. sp.}

\section{(P1. XXVII, fig. $6 a, b)$.}

Puparium of female (fig. $6 a$ ) circular, the larval pellicle projecting beyond the margin; slightly convex above. Colour clear white, the pellicles castaneous. Average diameter $2 \mathrm{~mm}$.

Male puparium white: strongly tricarinate. Length approximately I $\mathrm{mm}$.

Adult female ovate; length approximately equal to twice the breadth. Pygidium (fig. 6b) broadly rounded. Median lobes occupying a slight median depression; their bases united, their distal edges divergent, without serrations or indentations. Lateral lobes duplex, prominent; the first laterals distinct, the two lobules of approximately equal size; the second laterals in the form of thickened marginal prominences, the inner lobule with an oval dorsal pore at its base. Squames spiniform. Marginal spines inconspicuous. Anal orifice central. Circumgenital glands in five groups, with numerous pores; median group I6 to 25 ; upper laterals 30 to 42 , lower laterals 29 to 28 . Oval dorsal pores conspicuous, in broken longitudinal curved series. Length $\mathrm{I}^{\circ} 5 \mathrm{~mm}$. Breadth approximately $0.75 \mathrm{~mm}$.

Massed on the stems of a large species of Bamboo. Gudalura, Nilgiris (coll. E. E. Green).

This is one of those species which reveal the close affinity between the Phenacaspis section of the genus Chionaspis and the Aulacaspis section of Diaspis, the chief distinction between which 
appears to be that in the former the larval pellicle is ultramarginal, while in the latter it is intra-marginal in position.

Chionaspis spiculata, n. sp.

(P1. XXVII, fig. $7 a-d, 8 e, f)$.

Puparium of female (fig. $7 a$ ) elongate and very slender ; straight, parallel-sided, posterior extremity tapering abruptly to a point, exuviae fulvous, secretionary appendix white, sides sloping upwards to a median ridge which extends the whole length of the puparium. Length 2.25 to $3 \mathrm{~mm}$; breadth approximately $0.25 \mathrm{~mm}$.

Male puparium not observed.

Adult female (fig. $7 d$ ) long and narrow, more than half the length occupied by the thoracic area. Pygidium (fig. $8 e, f$ ) without the usual chitinous lobes; but with a terminal series of longish acuminate processes ( 7 or 8 on each side) of which the median two are longer and stouter than the others. These processes are possibly homologous with the tubular squames of other species, but do not appear to be associated with any glandular ducts. Circumgenital glands in five groups, the upper three forming a more or less continuous arch : average number of pores,-median 2 , upper laterals 4, lower laterals 7 to 8 . Dorsal pores large and conspicuous (see fig. 8\%), sausage-shaped, placed transversely. Diagonal series of similar pores on each side of the abdominal segments, Anterior spiracles with 3 or 4 parastigmatic pores. Length I to $\mathrm{I} \cdot 25 \mathrm{~mm}$.

Nymphal pellicle (fig. $7 b$ ) narrow, acuminate behind: the posterior extremity (fig. $7 c$ ) with six prominent, slender, acuminate processes.

On foliage of Bambusa sp. Peria Ghat, N. Malabar, $2000 \mathrm{ft}$. (Ramakrishna, No. I26-part).

This is a very distinct insect, quite unlike any other known species. It is placed provisionally in the genus Chionaspis, pending the discovery of the male puparium.

Chionaspis (Phenacaspis) varicosa, Green.

(P1. XXVIII, fig. 9).

Green, "Cocc. Ceylon," II, p. 146, pl. L (1899).

On Loranthus, Dodabetta, Nilgiris (Ramakrishna, No. 74), and on Piper sp. Coorg, Sidapur (Ramakrishna, No. 62).

The Indian form (fig. 9) has the median lobes rather more strongly divaricate than in typical examples from Ceylon, and shows a single spiniform squame on the margin of the fourth space, in place of the group of three or four that occur in the same position in typical examples. The female puparium, also, is longer and narrower than in the type, and does not exhibit the conspicuous raised lines that characterize examples from Ceylon. 
Chionaspis acuminata, Green.

On Evodia. Peria Ghat, North Malabar, 2,0oo ft. (Ramakrishna, No. I27-part).

Chionaspis acuminata var atricolor, Green.

On Tamarindus and Carissa. Coimbatore (Ramxkrishna, Nos. I24 and I47).

Chionaspis elongata, Green.

On Bambusa sp. Ootacamund (coll. E. E. Green).

Chionaspis litseae, Green.

On 'Ghumti.' Darjiling District. (Ex coll. Ind. Mus.).

Chionaspis megaloba, Green.

On Zizyphus jujuba. Pusa (T. B. Fletcher, No. 44).

Hemichionaspis chionaspiformis, Newst.

On 'Wild Indigo.' Coimbatore (Ramakrishna, No. I22).

Dinaspis permutans (Green).

On Evodia. Peria Ghat, 2,ooo ft., N. Malabar (Ramakrishna, No. [27-part).

\section{Aspidiotus (Hemiberlesia) pseudocamelliae, n. sp.}

(P1. XXVIII, fig. Io).

Puparium of adult female ochraceous (when on the twigs or the upper surface of the foliage), whitish (on undersurface of foliage): pellicles darker ochreous, occupying the greater part of the area of the scale. Form irregularly circular, slightly convex above. Diameter 0.75 to I $\mathrm{mm}$.

Male puparium slightly paler in colour: ovate. Length $0.75 \mathrm{~mm}$.

Adult female broadly ovate: bluntly pointed behind. Pygidium (fig. Io) with a single median pair of large prominent lobes, their inner edges converging and rather closely approximated, their free edges sloping steeply and indented at one or two points. Squames very slender and inconspicuous, spiniform, obscurely pectinate outwardly: the three or four outermost squames each on a slight prominence. Marginal spines long and conspicuous. A well-marked claviform paraphysis running inwards from the outer edge of each median lobe. Anal orifice ovate; distant from the posterior extremity by about a quarter the length of the pygidium. No circumgenital pores. Oval dorsal pores conspicuous: in two irregular series on each side. Length 0.5 to $0.75 \mathrm{~mm}$. 
Thickly clustered on the smaller twigs and on both surfaces of the leaves of Capparis stylosa. Ittige, Bellary District (Ramakrishna. No. 64).

The species differs from camelliae in the nature of the squames, which are not broadly pectinate, as in that species, and in the greater number and size of the oval dorsal pores. The puparia, also, are quite distinctive.

\section{Aspidiotus tamarindi, n. sp.}

(P1. XXVIII, fig. II $a, b)$.

Female puparium irregularly oval or subcircular, flattish. Colour stramineous, ochreous, or pale castaneous, the darker examples being situated on the upper surface of the leaves. Diameter $2 \mathrm{~mm}$.

Male puparium small : oblong oval, slightly narrower behind. Colour rather paler than that of the female scale, occasionally whitish. Length $0.75 \mathrm{~mm}$.

Adult female (fig. I $a$ ) evenly turbinate, without any indications of abdominal segmentation. Pygidium somewhat produced: the margin (fig. II $b$ ) with six prominent, somewhat narrow lobes; all the lobes with a translucent band across the base; the median lobes are markedly indented on each side; the lateral lobes indented on the outer side only. Squames very thin and delicate, the distal extremity of each deeply fringed; those in the interlobular spaces ligulate; the ultra-lobular squames (of which there are six or seven on each side) broader, and acutely pointed at the inner edge. Anal orifice small, circular, approximately central. Circumgenital glands in four groups; the upper groups with 7 or 8 , and the lower with 3 or 4 pores. Numerous slender filiform ducts communicate with inconspicuous marginal (and ? dorsal) pores. Length I to $I^{\cdot} 25 \mathrm{~mm}$.

On Tamarindus. Coimbatore (Ramakrishna, No. 26-part).

Crowded on both surfaces of the leaflets. Male puparia intermingled with those of the females.

Aspidiotus cyanophylli, Sign. part).

On 'Ceara Rubber.' Nilgiris, 2,ooo ft. (Ramakrishna, No. 53-

Aspidiotus hartii, Ckll.

On Curcuma. Poona (H. H. Mann, No. 34).

Aspidiotus rossi, Mask.

On Carissa carandas. Coimbatore (Ramakrishna, No. 36).

On 'Pomegranate.' Bilaspore, C.P. (T.B. Fletcher, No. 38).

\section{Odonaspis penicillata, Green.}

On Bambusa. Coimbatore (Ramakrishna, No. I34-part). 


\section{Odonaspis simplex? (Green).}

On Bambusa. Coimbatore (Ramakrishna, No. I34-part).

\section{Aonidia indica, 11. sp. \\ (P1. XXVIII, fig. I2 $a, b)$.}

Puparium of female circular, moderately convex, the median area usually depressed or slightly concave; secretionary margin very narrow, the centre of the scale usually bare. Colour pale castaneous, the secretionary margin grayish brown. Diameter approximately $0.5 \mathrm{~mm}$.

Male puparium larger; broadly ovate; the larval pellicle nearer one extremity. Colour dull grayish brown. Length 0.75 $\mathrm{mm}$.

Adult female circular, the pygidium slightly prominent. Posterior extremity of pygidium (fig. I $2 a$ ) somewhat truncate; with eight small rounded or slightly indented lobes, the median pair largest, the others decreasing in size to the outermost. Between the lobes are some delicate fimbriate or truncate squames, and there are three or four similar squames beyond the outermost lobe, on each side. Anal orifice relatively large, near the posterior extremity. Length approximately $0.5 \mathrm{~mm}$.

Posterior margin of nymph (fig. I2h) with six prominent lanceolate lobes, the median pair slightly indented on each side. There are also six large and conspicuous semilunar marginal pores.

On undetermined plant. Museum Compound, Calcutta ( $N$. Annandale).

\section{Aonidia tentaculata, n. sp.}

(P1. XXIX, fig. I $3 a-d)$.

Female puparium flattish, dull castaneous, consisting of the large, naked nymphal pellicle upon which is superimposed the smaller larval pellicle - of a darker shade of brown. The nymphal pellicle is of the peculiar form shown at fig. I $3 a$, the thoracic area widely expanded, subcircular, the narrow parallel-sided abdominal area projecting posteriorly. The substance of the pellicle is densely chitinous, with a markedly granular structure, and with concentric series of irregularly oval clearer spaces. There is a sharply defined narrow marginal border. The posterior extremity of the pellicle (fig. ${ }^{3} b$ ) exhibits six well defined lobes, of which the median pair is very small and slender, the others broader and hastate in form. The intervals between the lobes are occupied by broad ligulate squames, and there are three obscurely dentate squames immediately exterior to the outermost lobe. The margin beyond the lobes is deeply incised at seven or eight points, and there are seven conspicuous lunate pores on each side. Length I mm. Width of thoracic area I mm., of abdominal area $0^{\circ} 3 \mathrm{~mm}$.

Adult female (fig. I3c) with thoracic area broadly crescentic ; the projecting pygidium tapering to a sharp point, its distal 
extremity with a marginal series of sixteen long and slender spathulate processes (fig. I $3 d$ ), beyond which is a single strong marginal spine on each side. Three small blunt projections on each side probably represent rudimentary pygidial lobes. Length $0.75 \mathrm{~mm}$. Breadth $0.75 \mathrm{~mm}$.

On Vateria indica. Quilon, Travancore (Ramakrishna, No. I46-part). Associated with Websteriella vaieriae.

The species is well characterized by the remarkable spathulate tentacle-like processes on the pygidium.

Aonidia crenulata, Green.

On Vatica lanceifolia. "Makum Forest, Assam" (Lindinger).

Aonidia dentata, Lindinger.

On Walsura piscidia. " Kamlekum Hill, India”' (Lindinger).

Aonidia spinosissima, Lindinger.

On Mimusops hexandra. "Central-India" (Lindinger).

Aonidia targioniopsis, Lindinger.

On Miliusa velutina. " Burma”' (Lindinger).

Aonidia viridis, I,indinger.

On Aglaia minutiflora. Travancore (Lindinger).

Gymnaspis ficus, n. sp.

(P1. XXIX, fig. I $4 a, b)$.

Puparium of female consisting of the swollen nymphal pellicle, sometimes with a superimposed larval pellicle: very broadly ovoid, strongly convex. Colour ochreous yellow, the centre with a dark patch where the colour of the dried insect shows through the semitranslucent scale. Length $0.6 \mathrm{~mm}$. Breadth $0.5 \mathrm{~mm}$.

Male puparium oblong: consisting of the yellowish larval pellicle at the anterior extremity, and a white secretionary appendix. Strongly convex on the anterior half, depressed behind. Length $0.75 \mathrm{~mm}$. Breadth $0.5 \mathrm{~mm}$.

Posterior margin of nymphal pellicle (fig. I $4 a$ ) with six narrow lanceolate, prominent lobes: the median pair strongly indented on each side, the lateral lobes indented weakly on the inner but more strongly on the outer side. ' Two large and conspicuous lunate pores on each side, situated in the interlobular spaces, and two or three similar but smaller pores beyond the lobes. Squames broad and deeply fringed.

1 The lithographic artist has not reproduced quite correctly the outline of these marginal lobes. 
Adult female subcircular or broadly oval. Rostral apparatus very large and conspicuous. Pygidium (fig. I4 $b$ ) rounded, the margin serratulate at the extremity. A denser chitinous area surrounds the anal orifice and extends to the genital region.

On Ficus retusa. Kollegal, Coimbatore (Ramakrishna, No. 22).

\section{Gymnaspis ramakrishnae, n. sp.}

(P1. XXIX, fig. I5a-f).

Female puparium consisting of the enlarged nymphal pellicle alone, the larval pellicle a!most invariably becoming detached during the later growth of the nymph. The nymphal pellicle (fig. $I_{5} c, d$ ) is broadly oval in outline, with a sharply defined pygidial area, in front of which the disc of the dorsum rises abruptly into a rounded dome-like protuberance. A lateral view (see fig. $5_{5} d$ ) is suggestive of the shape of one of the shrapnel helmets used by our troops during the recent war. Length approximately $0.5 \mathrm{~mm}$.

The early nymph (fig. $\mathrm{I}_{5} \mathrm{e}$ ) is of the same contour, but shows no sign of the dorsal elevation. The pygidial area is strongly demarked, and recessed into the abdominal segments. The pygidial fringe (fig. $\mathrm{I} 5 f$ ) is like that of a typical Parlatoria, with six small but prominent lobes and broad fimbriate squames.

Adult female (fig. I5x) subspherical; the pygidial area slightly projecting, weakly chitinized and with its inner boundary ill defined. Rostral apparatus large and conspicuous. Pygidium (fig. $5_{5} b$ ) with two very small tricuspid lobes which are recessed into the margin. Between the lobes is a single prominent median process, and there are two similar processes (? modified squames) immediately exterior to each lobe. Anal orifice comparatively large, approximately central. Length 0.25 to $0.3 \mathrm{~mm}$.

On undersurface of leaves of Hemigyrosa, disposed-principally-along the prominent veins. Courtallum, Tinnevelli (Ramakrishna, No. I40).

\section{Parlatoria artocarpi, n. sp.}

(P1. XXIX, fig. I6).

Puparium of female castaneous, with a blackish medio-longitudinal vitta; broadly ovate; consisting of the nymphal exuviae alone, without any secretionary appendix. Nymphal pellicle unusually large. Length 0.8 to $0.9 \mathrm{~mm}$.

Male puparium narrower and slightly longer; larval pellicle dull greenish-olivaceous; appendix white. I.ength I mm.

Adult female entirely concealed beneath the large nymphal pellicle. Of normal form; broader across the metathoracic area. Pygidium (fig. I6) with six prominent tricuspid lobes. A large and densely chitinous lunate marginal pore in each inter-lobular space, and smaller lunate pores at intervals along the margin beyond the lobes. The paired squames that occupy the inter-lobular spaces 
are ligulate, irregularly serrate distally, the outer edges of each pair markedly longer than the inner edges, so that the distal margins of the two squames slope in opposite directions. The squames that lie outside the lobes are of irregular form; those nearest the lobes being comparatively broad, the remainder decreasing in width till, towards the base of the pydidium, they become long and slender. There are three tooth-like marginal prominences on each side, situated respectively after the $3 \mathrm{rr}, 7$ th and IIth squames, the last sometimes obsolescent. On the margins of the abdominal and post-thoracic segments the fimbriate squames are replaced by narrow, tapering, tentacle-like processes, similar to those at the extreme base of the pygidium. Anal orifice approximately central, surrounded by a narrow denser chitinous border. Circumgenital glands in four groups, each containing from 7 to 8 pores. A few small oval (or obscurely crescentic) dorsal pores, in pairs, near the margin of the pygidium. Length $0^{\circ} 5$ to $0^{\circ} 75 \mathrm{~mm}$.

On upper surface of foliage of ' jak' (Artocarpus integrifolia). Peria Ghat, North Malabar (Ramakrishna, No. I28).

Characterized by the large nymphal pellicle, absence of secretionary appendix, and the tentacular marginal processes.

\section{Parlatoria (Websteriella) papillosa, n. sp.}

$$
\text { (P1. XXX, fig. I } 7 a-g) \text {. }
$$

Puparium of female (fig. $I 7 b, c$ ) minute; oval; consisting of the nymphal pellicle without any secretionary appendix, the disc rising abruptly into a hemispherical boss. Colour bright yellow or ochreous, the median elevation jet black. Length $0^{\circ} 5 \mathrm{~mm}$.

Male puparium (fig. I $7 a$ ) creamy white or very pale ochreous, the larval pellicle dusky olivaceous; elongate ovate, broader in front, appendix moderately convex, with a broad medio-longitudinal depressed groove. Length $0^{\circ} 7 \mathrm{~mm}$.

Adult female (fig. I 7 ) broadest across the anterior thoracic area, tapering behind. Mouth parts large and conspicuous. Margin of meso-thorax with a series of from Io to 12 minute rounded papillae (see fig. I7e). Margins of metathorax and abdomen with a rather distant series of truncate conical papillae. Pygidium (fig. I $f$ ) with median and lateral lobes represented by densely chitinous deltoid marginal prominences. The space between the median lobes is occupied by a single prominent broadly spathulate process; two similar but smaller processes occupy the space between the median and first lateral lobes, followed by three similar processes in the next interval. These processes apparently take the place of the deeply fimbriate squames that occur in the same positions in typical members of the genus. There are five conspicuous lunate pores situated immediately above the spaces occupied by the spathulate processes, and usually-but not invariably-a similar pore further up the margin on each side. Circumgenital glands in four groups, the upper lateral groups with six pores, the 
lower laterals with from three to four pores. Anal orifice approximately central. Length $0_{4} 4 \mathrm{~mm}$.

Posterior extremity of nymphal pellicle (fig. I7g) with six conical lobes, each placed on a sharp marginal prominence. There are six large and conspicuous lunate marginal pores in the deeply incised spaces between the lobes. Squames broad and deeply fimbriate at their extremities.

On Artocarpus integrifolia. Palghat (Ramakrishna, No. I37).

The insect has anomalous characters, - notably, the single median process on the pygidium of the aduit female,-which might justify the erection of a separate sub-genus for its reception. But, until other allied species have been discovered, it may remain in the present genus. It most nearly approaches Leonardi's sub-genus Websteriella.

\section{Parlatoria vateriae, n. sp.}

(P1. XXX, fig. I $8 a-e)$.

Female puparium irregularly ovate, flattish; consisting of the larval and nymphal exuviae, without any secretionary appendix. Larval pellicle slightly projecting beyond the anterior margin of the nymphal pellicle; subcircular; very pale stramineous, the centre slightly greenish. Nymphal pellicle (fig. I $8 a$ ) stramineous or pale fulvous, translucent, marginal area darker ; elongate ovate, narrower behind. Posterior extremity (fig. I $8 b$ ) with rather small and narrow tricuspid lobes; lunate marginal pores strongly developed; squames either entire or obscurely dentate, broad. There is a sharply defined cleft between the median pair of squames, extending inwards as far as the anal orifice. Length of nymphal pellicle 0.85 to $0.9 \mathrm{~mm}$. Total length of puparium I $\mathrm{mm}$.

Adult female (fig. I $8 c$ ) minute, entirely covered by the nymphal pellicle. Thoracic area and pygidium rigid and indurated, the former with a small translucent oval space on each side of the rostrum; abdominal segments soft and flexible. Anterior margin broadly rounded; body widest across the base of the abdomen; thence narrowed abruptly. Rudimentary antennae (fig. I $8 c$ ) in the form of a ring with a radiating series of stout but short setae. Pygidial area sharply defined; base rounded, the extremity. (fig. I8d) rather pointed; with six small obscurely tricuspid lobes; two small and inconspicuous lunate marginal pores on each side, squames long and narrow, projecting far beyond the lobes, sharply pointed, some of them obscurely dentate or fimbriate on their lateral margins: circumgenital glands in four groups, the upper laterals with 7 or 8 pores, lower laterals with 4 or 5 . Length approximately $0.5 \mathrm{~mm}$. part).

On Vateria indica. Quilon, Travancore (Ramakrishna, No. I46-

This insect, with its long sharply pointed squames and reduced semilunar pores, is very distinct from any other known species of Parlatoria; but may-for the present-be included in Leonardi's sub-genus Websteriella. 
Parlatoria calianthina, Beri. and Leon.

(P1. XXX, fig. I9).

On Mangifera. Rajputana Provinces (T. Bainbrigge Fletcher); and on Nerium and Michelia. Madras (Ramakrishna).

Typical examples of the species are distinguished from pergande $i$ by the presence of a fifth (median) group of circumgenital glands, containing from I to 3 pores; by the broader and more densely chitinous pygidial lobes; and by the smaller and less pectinated marginal squames. I find, however, after examination of much material, from various localities and host plants, that the presence of the median group of pores is by no means constant and-in some gatherings-is actually exceptional. Fig. I9 shows the pygidium of an example from Michelia champaca, in which the median group is absent.

Parlatoria pergandei, Comst.

On Garcinia cowa. "Singbhum, India” (Lindinger).

Parlatoria (Websteriella) atalantiae, Green.

On Miliusa indica. Courtallum (Lindinger).

Lepidosaphes meliae, n. sp.

(P1. XXX, fig. 20a-c).

Puparium of female clear ochreous brown, but usually appearing dark brown from the inclusion of fragments of the cortex of the plant. Mytiliform; straight or variously curved; moderately convex in transverse section. Larval pellicle reddish ochreous. Nymphal pellicle concealed. Total length averaging $2.5 \mathrm{~mm}$.

Nymphal pellicle with two series of irregular translucent lacunae on each side of the cephalic area, the outermost series sometimes partially double. Length averaging $0.75 \mathrm{~mm}$.

Male puparium dark brown; posterior extremity whitish; larval pellicle reddish ochreous. Narrow; margin somewhat sinu- ous. Length I'25 $\mathrm{mm}$.

Adult female broadest across base of abdomen. Median area of abdomen somewhat heavily but irregularly chitinized. Lateral area of second segment of abdomen with a transverse patch (fig. 20a) of stout conical spiniform spinnerets, each of which has a short tubular extension at its apex (fig. 20b). Pygidium (fig. 2oc) considerably broader than long; the median lobes broad and prominent, adjacent, the apices towards the median line: lateral lobes duplex, the inner lobe large, sloping away from the inner edge, the outer lobule minute: long chitinous paraphyses extend inwards from each lobe. Beyond the lobes, on each side, are three marginal prominences, the inner two moderately cristate and rather heavily chitinized. Squames spiniform. Circumgenital 
glands in five groups; the median group with from 8 to II pores, upper laterals with an average of 20 , lower laterals averaging I4. Dorsal pores minute, circular. Length averaging $I^{*} \mathrm{I} 5 \mathrm{~mm}$.

On 'Nim tree' (Melia azedarach). Coimbatore (Ramakrishna, No I49).

\section{Lepidosaphes retrusus, n. sp.}

(P1. XXXI, fig. 2I).

Puparium of adult female dull ochreous brown to reddish brown; occasionally with an incomplete superficial layer of whitish secretion; usually overlaid with hairs and extraneous matter from the leaf upon which it rests. Rather strongly but irregularly convex; often distorted; usually broadest across the middle, but sometimes wider behind. Length $\mathrm{I}^{\prime} 25$ to $\mathrm{I}^{\prime} 5 \mathrm{~mm}$.

Male puparium brighter ochreous brown; moderately convex; narrow. Length $\mathrm{I} \mathrm{mm}$.

Adult female broadly ovate. Pygidium obtuse; median area more densely chitinous. Median lobes large and prominent, the free edges strongly but irregularly dentate--with from 6 to 8 denticles. First lateral lobes usually duplex, the inner lobule largest and obscurely bi-dentate, the two lobules occasionally coalescing to form a single tri-dentate process. Second lateral lobes smaller, obscurely tri-dentate. Squames spiniform, stout, a paic in each of the spaces between the median and the lateral lobes, and a third pair shortly beyond the outermost lobe. Anal orifice oblate, close to the base of the pygidium. Circumgenital glands in five groups, the median group with from 6 to I2 pores, the upper laterals with from 8 to I 8 , and the lower laterals with II to I 8 . Oval dorsal pores of two sizes; three very large pores on each side near the margin, and numerous smaller pores, in irregular scattered series. Length 0.5 to $0.75 \mathrm{~mm}$.

On the undersurface of leaves of Litsea whiteana, arranged along the mid-rib and principal veins. Dodabetta, 8,00o ft., Nilgiris (Ramakrishna, No. 73).

Lepidosaphes auriculatus, Green.

On Codiaeum. Calcutta (H. M. Lefroy).

\section{Lepidosaphes pallidus, Green.}

On Psidium. Ramchandrapur, Godaveri District (Ramakrishna, No. I05)

Lepidosaphes travancoriensis, Lindinger.

On Aglaia minutiflora. Travancore (Lindinger).

Ischnaspis spathulata, Lindinger.

On Vatica obscura. "W. Palukananda, Jumpalai" (Lindinger). 
Fiorinia frontecontracta, n. sp

(P1. XXXI, fig. 22a-d).

Puparium of female pale castaneous, usually with a darker medio-longitudinal stripe running through both larval and nymphal pellicles. Little or no secretionary appendix. Elongate; narrow; with a distinct medio-longitudinal ridge. Length 2 to $2.25 \mathrm{~mm}$. Breadth across middle $0.5 \mathrm{~mm}$.

Nymphal pellicle (fig. 22c) elongate; narrow; anterior extremity with a sharply defined depressed area where it is overlapped by the larval pellicle. Margin of abdominal area with two (sometimes three) prominent thorn-like spines on each side. Margin of posterior extremity (fig. 22d) with well-developed median and lateral lobes; the former surk in a median excision, wide apart and divergent, their free margins minutely serrate; the lateral lobes duplex, the inner lobule larger and more prominent. Length of pellicle $\mathrm{I} \cdot 75 \mathrm{~mm}$.

Male puparium white; larval pellicle pale stramineous. The white secretionary appendix wider towards the posterior extremity; flattish, with a single (often obscure) medio-longitudinal carina. Length I to I $25 \mathrm{~mm}$.

Adult female (fig. 22a) with the anterior extremity contracted and transversely wrinkled. Rudimentary antennae conspicuous; each with a stout curved seta. No inter-antennal tubercle. Mouth-parts large and conspicuous. Form narrow at anterior extremity, gradually widening behind; broadest immediately above the pygidium; abdominal segments retracted. Pygidium (fig 22b) with circumgenital glands forming an almost continuous arch; the upper and lower lateral groups confluent, together containing from 35 to 40 crowded pores, connected above by a loose series of 5 or 6 pores representing the median group. Median lobes well developed; recessed; rather widely separated; of irregular form, broadest across the base, the free edge coarsely and irregularly dentate. Lateral lobes minute, inconspicuous. Three conspicuous conical marginal prominences project on each side of the pygidium - one immediately exterior to the median lobes, a second exterior to the lateral lobes, and the third about half way between the last and the base of the pygidium. Closely following upon each of the second and third prominences is a shallow recess with its margin conspicuously thickened. Length approximately $0.75 \mathrm{~mm}$.

On foliage of Garcinia indica. Bombay (H. H. Mann, No. 4I).

Fiorinia plana, n. sp.

(P1. XXXI, fig. 23a, b).

Puparium of female pale stramineous, translucent; elongateovate, flattish or slightly convex above; consisting of the larval and nymphal pellicles, with little or no secretionary appendix. Larval pellicle small. Nymphal pellicle enlarged, the pygidial area depressed; posterior margin (fig. $23 b$ ) with prominent median 
and lateral lobes, all of which are narrow at the base and broadly expanded distally, the extremities squarely truncate. I,ength of puparium I. 75 to $2 \mathrm{~mm}$.

Male puparium not observed.

Adult female with the abdominal segments strongly retracted. I have been unable to detect any trace of either antennae or interantennal tubercle. Lateral margins of thorax and abdomen with scattered tuberculate spines. Spiracles without parastigmatic pores. Pygidium (fig. 23a) with five groups of circumgenital glands; the median group with four widely separated pores, the upper laterals averaging I I and the lower laterals I 5 pores. Posterior margin with the median lobes rather widely separate, their distal extremities sharply and irregularly dentate; lateral lobes duplex, both lobules unusually broad, contiguous or more or less confluent, their free margins strongly dentate. Length of extended example I mm. Retracted examples 0.5 to $0.75 \mathrm{~mm}$.

On upper surface of leaves of Elaeodendron glavcum. Coimbatore (Ramakrishna No. I39).

Fiorinia sapindi, n. sp.

(P1. XXXI, fig. $24 a-d)$.

Female puparium covered almost completely by the nymphal pellicle, with sometimes a very narrow colourless secretionary margin. Pellicles dark castaneous, lighter towards the margins. Length I to $\mathrm{I} \cdot 35 \mathrm{~mm}$.

Nymphal pellicle (fig. 24a) rather narrow; the posterior abdominal segments with lateral margin produced into small but acute points. Posterior extremity (fig. $24 b$ ) with a very large pair of median lobes which are widely divaricate and recessed into the margin, first lateral lobes duplex, the inner lobule longer than the other: second lateral lobes tridentate. Length I to I'25 mm.

Adult female minute, with very thin and delicate derm. Antennae (fig. 24c) consisting of a pair of obscurely dentate tubercles, each with a longish curved bristle on the outer side, a slight fold between the antennae. Posterior extremity (fig. $24 d$ ) with small but prominent median lobes, set rather wide apart, with a lunate chitinous plate between them. Lateral lobes represented by a small conical prominence on each side. There is a pair of long slender spines between the median lobes, and other similar spines are set at intervals along the margin. Circumgenital glands consisting of a practically continuous arch containing about 50 pores. Length $0.5 \mathrm{~mm}$.

On Sapindus trifoliatus. Poona (H. H. Mann, No. 20).

Fiorinia odinae, Leonardi, var. multipora, Lindg. On Taxus wallichiana. "Khasia, India"' (Lindinger).

Fiorinia saprosmae, var. geloniae, Green.

On Gelonium. Ootacamund (coll. E.E.G.) 
I9I9.]

E. E. GREEN : Indian Coccidae.

Leucaspis indica, Marlatt.

On Mangifera indica. Poona (H. H. Mann, No. 35).

Leucaspis japonica, Ck11. and 93).

On Ficus religiosa. Calcutta. (Ex coll. Ind. Mus., Nos. 60

Leucaspis salicis, Green.

On Salix sp. Baluchistan (V. Iyer). 


\section{$2 \mathrm{BHL}$ Biodiversity Heritage Library}

1919. "Notes on Indian Coccidae of the sub-family Diaspidinae, with descriptions of new species." Records of the Indian Museum 16, 433-449. https://doi.org/10.5962/bhl.part.25932.

View This Item Online: https://www.biodiversitylibrary.org/item/41759

DOI: https://doi.org/10.5962/bhl.part.25932

Permalink: https://www.biodiversitylibrary.org/partpdf/25932

\section{Holding Institution}

MBLWHOI Library

\section{Sponsored by}

MBLWHOI Library

\section{Copyright \& Reuse}

Copyright Status: Public domain. The BHL considers that this work is no longer under copyright protection.

This document was created from content at the Biodiversity Heritage Library, the world's largest open access digital library for biodiversity literature and archives. Visit BHL at https://www.biodiversitylibrary.org. 